\title{
PENGARUH SERVICESCAPE DAN HARGA TERHADAP KEPUASAN PENGUNJUNGDI MUSEUM ANGKUT MOVIE STAR STUDIO KOTA BATU
}

\author{
Sri Wilujeng \\ Fakultas Ekonomi dan Bisnis Universitas Kanjuruhan Malang \\ Email:media_myajeng@yahoo.co.id
}

\begin{abstract}
The purpose of this research is to find out the influence of servicescape and price to the satisfaction of visitors. This research was conducted at Museum Angkut Movie Star Studio Kota Wisata Batu. Samples of this study are 120 respondents, through purposive sampling method. Data collection was done through observation and questionnaires. Based on the analysis multiple linear regression research shown that servicescape and prices simultaneous effect on satisfaction of visitors. Servicescape and prices partial effect on satisfaction of visitors. Servicescape predominantly affect the satisfaction of visitors.
\end{abstract}

Keywords: servicescape, price, satisfaction, visitors

Perkembangan sektor pelayanan jasa saat ini berkembang cukup pesat dan membawa perubahan pada pola hidup masyarakat yang tentu berdampak pada meningkatnya tingkat kebutuhan hidup masyarakat akan jasa. Perusahaan jasa harus mencari cara yang inovatif guna meningkatkan keunggulan kompetitif agar dapat menjaga hubungan jangka panjang dengan konsumen. Dewasa ini, pariwisata merupakan suatu kebutuhan penting manusia, baik bagi masyarakat yang melakukan perjalanan wisata (wisatawan) maupun masyarakat sekitar daerah tujuan wisata. Melancong atau wisata adalah bepergian jauh dengan tujuan sekedar lihat-lihat, senang-senang dan menghibur hati. Hukum asal bepergian semacam ini adalah diperbolehkan asalkan sekedar untuk refreshing agar tidak bosan menghadapi beban dan tuntutan hidup yang menumpuk. Kegiatan semacam ini tak ubahnya istirahat sebentar dari berbagai aktivitas agar jiwa dan badan kembali energik dan fresh seperti firman Allah dalam QS An Naml: 60

Artinya: "Atau siapakah yang telah menciptakan langit dan bumi dan yang menurunkan air untukmu dari langit, lalu Kami tumbuhkan dengan air itu kebun-kebun yang berpemandangan indah" (QS an Naml:60).

Namun jika motivasi wisata adalah karena menikmati betapa indahnya kehidupan dunia ini dan karena adanya kecenderungan hati kepada dunia serta merasakan nikmatnya hidup di dunia maka wisata dengan tujuan semacam ini itu tercela. Ini dikarenakan menganggap baik suatu yang kurang bernilai yaitu dunia dengan meninggalkan yang lebih baik yaitu akherat. Syeikhul Islam Ibnu Taimiyyah mengatakan, "Melihat-lihat pepohonan, sungai dan bunga-bunga jika karena motivasi penilaian betapa indahnya dunia, kekuasaan dan harta benda maka ini adalah suatu yang tercela mengingat firman Allah dalam QS Thoha: 131

Artinya, "Dan janganlah kamu tujukan kedua matamu kepada apa yang telah Kami berikan kepada golongan-golongan dari mereka, sebagai bunga kehidupan dunia untuk Kami cobai mereka dengannya" (QS Thoha:131)"

Oleh karena itu, ketika seorang muslim mengadakan kegiatan wisata hendaknya dia berniat untuk refreshing, mengembalikan semangat untuk beraktivitas serta untuk memikirkan makhluk ciptaan Allah dan kemahakuasaan Allah. Sehingga benarlah firman Allah tentang orang-orang yang beriman,

Artinya, "Dan mereka memikirkan tentang penciptaan langit dan bumi (seraya berkata), "Ya Tuhan Kami, Tiadalah Engkau menciptakan ini dengan sia-sia" (QS Ali Imron:191).

Kota Batu merupakan kota di Jawa Timur yang terkenal dengan keberagaman tempat wisatanya. Kota Batu terletak 800 meter dari permukaan laut dan memiliki suhu yang dingin dan sejuk sekitar 1725,6 derajat celcius, dikarenakan dikelilingi oleh pegunungan. Kondisi geografis Kota Batu yang baik dan 
cocok untuk daerah tujuan wisata membuat pemerintah daerah dan pihak swasta banyak mengembangkan dan membangun tempat wisata yang membawa efek terhadap pendapatan daerah. Banyaknya tujuan wisata serta image sebagai kota wisata membawa dampak banyaknya wisatawan lokal dan asing yang datang ke Kota Batu.

Kota Batu memiliki banyak lokasi tujuan wisata dengan jenis tema berbeda, dari wisata alam hingga wisata buatan. Kondisi geografis yang sejuk membuat Kota Batu memiliki banyak tujuan wisata alam. Seiring dengan semakin dinamis dan pola pikir masyarakat yang modern membuat kebutuhan akan tempat wisata berkambang tidak hanya pada wisata alam dan budaya. Kini banyak dibangun wisata buatan di Kota Batu dengan berbagai tema tidak hanya terfokus pada wisata wahana tapi juga wisata untuk pembelajaran. Demi mewujudkan manusia yang mampu bertahan dalam era globalisasi, berbagai upaya perkembangan dan peningkatan kualitas pendidikan di Indonesia terus dipacu. Museum merupakan tempat historial yang sangat membantu pendidikan mengenai sejarah sehingga diharapkan mampu memberikan dampak munculnya rasa simpati, empati dan menghargai serta menghormati asal mula ataupun segala kejadian yang ada pada masa lampau. Karena semua perkembangan yang ada pada saat ini merupakan hasil pembelajaran di masa lalu. Dewasa ini, dunia terasa menjadi lebih dekat dan mudah dengan adanya berbagai alat angkut. Alur perdagangan dan perekonomian menjadi lebih luas dengan memanfaatkan berbagai alat angkut mulai dari alat angkut udara, angkutan darat, dan angkutan air yang terus mengalami perkembangan. Pada awalnya, fungsi alat angkut merupakan alat yang digunakan untuk memudahkan manusia untuk berpindah dari satu tempat ke tempat lainnya.

Terinspirasi dari bentuk penghargaan atas penciptaan alat transportasi di dunia. Kini telah hadir museum transportasi modern pertama di Indonesia dan Asia yang memadukan unsure seni dan budaya yaitu Museum Angkut Movie Star Studio. Museum Angkut Movie Star Studio sendiri merupakan museum dengan konsep education dan entertainment yang ditampilkan secara langsung ke pengunjung. Lokasinya berada dilereng Gunung Panderman di areal seluas 3,8 hektare. Museum Angkut Movie Star Studio memiliki 300 lebih koleksi jenis angkutan mulai tradisional sampai modern yang dipadukan dengan berbagai landscape dan model bangunan eksotis dunia mulai dari benua Eropa sampai Amerika. Di dalam Museum Angkut Movie Star Studio juga terda- pat wisata Pasar Apung yang menjajakan berbagai kuliner dan handycraft khas Nusantara. Meski terbilang masih baru, Museum Angkut Movie Star Studio mampu membuat trend baru bagi wisatawan untuk mengunjungi museum. Hal ini merupakan fenomena baru mengenai antusias masyarakat untuk mengunjungi wisata museum.

Perusahaan pariwisata harus mengetahui apa yang menjadi keinginan dan kebutuhan konsumen termasuk memahami perilaku dan hal-hal yang dapat memberikan kepuasan terhadap konsumen. Bukan hanya keunikan dari tempat wisata yang menjadi daya tarik sebuah tempat wisata, namun ada beberapa faktor lain, seperti yang dikemukakan Alma (2009) bahwa industri pariwisata harus memperhatikan faktorfaktor yang dapat mendorong permintaan konsumen, seperti fasilitas, kemudahan akses, harga, faktor produk itu sendiri, pelayanan waktu yang tepat dan sebagainya. Banyak faktor yang membuat konsumen puas dengan produk yang digunakan salah satunya adalah berkaitan dengan layanan fisik. Lovelock (2005) mendefinisikan servicescape atau lingkungan layanan sebagai gaya dan tampilan dari lingkungan fisik dan elemen-elemen pengalaman lainnya yang dirasakan oleh pelanggan di tempat pelayanan. Pengaplikasian servicescape di Museum Angkut Movie Star Studio tampak dalam visual di setiap zona sesuai dengan tema, latar belakang sejarah dan jenis angkutannya. Dengan unsur tematik yang berbeda-beda pada setiap zona memberikan para wisatawan ikut merasakan suasana yang tercipta pada zona tersebut. Museum Angkut Movie Star Studio menampilkan berbagai benda dan ornamen untuk menunjang pengunjung dalam mengenali suatu zona, oleh karena itu persepsi visual dibutuhkan pengunjung untuk mengenali suatu zona.

Perusahaan jasa juga harus merancang strategi pemasaran yang tepat, selain memikirkan pelayanan juga harus ada penetapan harga dalam produk yang akan dijual dikarenakan proses dalam suatu pembelian adalah dilalui oleh harga sebagai pertimbangan keputusan konsumen untuk membeli suatu produk. Harga adalah elemen bauran pemasaran yang menghasilkan pendapatan dan merupakan salah satu elemen bauran pemasaran yang fleksibel (Kotler, 2009).

Penetapan dan persaingan harga merupakan masalah yang dihadapi perusahaan untuk menarik keputusan konsumen agar melakukan keputusan pembelian atau berkunjung ke suatu tempat. Berdasarkan uraian di atas, maka tujuan dari penelitian ini adalah: untuk mengetahui pengaruh servicescape dan harga 
terhadap kepuasan pengunjung, serta mengetahui variabel yang berpengaruh dominan terhadap kepuasan pengunjung di Museum Angkut Movie Star Studio Kota Batu.

\section{Servicescape}

Servicescape adalah lingkungan fisik dimana jasa diberikan kepada konsumen (Lovelock, 2005). Sedangkan menurut Bitner dalam (Lengkong \& Lumanauw 2008) servicescape sebagai lingkungan buatan (built environment). Namun sejak awal servicescape telah menunjukan definisinya sebagai suatu lingkungan fisik yang memang sengaja diciptakan supaya mendukung layanan yang diberikan oleh suatu perusahaan atau jasa.

Lovelock (2005) yang membagi dimensi servicescape menjadi tiga bagian yaitu: (1) Ambient Conditions: merupakan karakteristik lingkungan yang berkenaan dengan kelima indera. Manusia dapat memikirkan serta merespon dari pelayanan yang ada di tempat tersebut. Selain itu aspek ini mempunyai karateristik latar belakang dari lingkungan sekitar seperti temperatur, pencahayaan, kebisingan, kualitas udara, musik dan warna; (2) Spatial Layout and Functionality, merupakan dalam layout,peralatan yang diatur dan kemampuan barang-barang untuk memfasilitasi kenikmatan konsumen; (3) signs, Symbols and Artifacts, merupakan tanda-tanda/ rambu serta dekorasi yang digunakan untuk berkomunikasi dan meningkatkan citra tertentu atau suasana hati, untuk memudahkan konsumen untuk mencapai tujuannya.

\section{Harga}

Menurut Lupiyoadi (2013) harga adalah berbagai manfaat yang dimiliki oleh suatu produk jasa yang dibandingkan dengan berbagai biaya (pengorbanan) yang ditimbulkan dalam mengonsumsi jasa tersebut. Biaya-biaya tersebut dapat berupa waktu yang harus dikorbankan untuk mendapat jasa, upaya fisik (energi yang dikeluarkan untuk mendapat jasa), beban mental (stres), dan pengorbanan yang terkait dengan pancaindera (suara bising, panas dan sebagainya). Pada kenyataannya, tingkat harga yang terjadi dipengaruhi oleh beberapa faktor.

Tjiptono (2011) mayoritas konsumen agak sensitif terhadap harga, namun juga mempertimbangkan faktor lain (seperti citra merek, lokasi toko, layanan, nilai (value), fitur produk, dan kualitas). Kotler (2009) berpendapat bahwa konsumen cenderung melihat harga akhir dan baru kemudian memutuskan apa nilai yang mereka terima memang baik.

\section{Kepuasan}

Kepuasan adalah tingkat perasaan seseorang setelah membandingkan kinerja (atau hasil) yang dirasakan dibandingkan dengan harapannya (Kotler, 2009). Menurut Wilkie dalam Tjiptono (2011) kepuasan adalah merupakan suatu tanggapan emosional pada evaluasi terhadap pengalaman konsumsi suatu produk atau jasa. Sedangkan menurut Engel, et al. dalam Tjiptono (2011) menyatakan bahwa kepuasan pelanggan merupakan evaluasi purna beli dimana alternatif yang dipilih sekurang-kurangnya sama atau melampaui harapan pelanggan, sedangkan ketidakpuasan timbul apabila hasil (outcome) tidak memenuhi harapan.

Dari beberapa definisi kepuasan tersebut menunjukkan bahwa seorang pelanggan mungkin mengalami berbagai tingkat kepuasan yaitu bilamana kinerja produk tidak sesuai dengan harapannya setelah dikonsumsi maka konsumen tersebut merasa tidak puas dan akan merasa kecewa, namun sebaliknya bila kinerja produk sesuai dengan harapannya maka pelanggan akan merasa amat puas sehingga diwaktu mendatang akan bergairah untuk mengkonsumsi produk itu kembali.

Menurut Tjiptono (2011) adanya kepuasan pelanggan dapat memberikan manfaat, diantaranya adalah: Hubungan antara perusahaan dan para pelanggannya menjadi harmonis; memberikan dasar yang baik bagi pembelian ulang; mendorong kepuasan sehingga terciptanya loyalitas pelanggan; membentuk suatu rekomendasi dari mulut ke mulut (word-ofmouth) yang menguntungkan bagi perusahaan; reputasi perusahaan menjadi baik dimata pelanggan dan laba yang diperoleh dapat meningkat.

\section{METODE}

Jenis penelitian adalah explanatory research untuk menjelaskan hubungan antara variabel- variabel melalui pengujian hipotesis (Singarimbum dan Effendy, 2012). Penelitian ini dilakukan dengan mengadakan survey pada populasi penelitian yaitu pengunjung Museum Angkut Movie Star Studio Kota Batu. Penelitian ini dilakukan dilakukan pada Museum Angkut Movie Star Studio Kota Batu yang beralamat di Jl. Terusan Sultan Agung No. 2 Kota Batu - Jawa Timur, Indonesia. Populasi yang digunakan dalam penelitian ini adalah pengunjung yang berada di 
Museum Angkut Movie Star Studio Kota Batu. Sampel yang diteliti sebanyak 120 responden.

Variabel bebas dalam penelitian ini adalah servicescape dan harga, dan variabel Terikat dalam penelitian ini adalah kepuasan pengunjung. Servicescape (X1) diukur dengan ambient condition, spatial layout and functionality, signs, symbols and artifacts (Lovelock, 2005). Harga diukur dengan daya saing harga, keterjangkauan harga, keseuaian harga dengan kualitas (Tjiptono, 2008). Kepuasan diukur dengan konfirmasi harapan, minat untuk penggunaan ulang, kesediaan untuk meromendasikan (Tjiptono, 2011).

Metode analisis data menggunakan Analisis Regresi Linear Berganda, yaitu untuk mengukur pengaruh servicescape dan harga terhadap kepuasan pengunjung. Hipotesis dalam penelitian ini adalah: servicescape berpengaruh terhadap kepuasan pengunjung; harga berpengaruh terhadap kepuasan pengunjung.

\section{HASIL DAN PEMBAHASAN}

\section{Hasil Uji Parsial (t)}

Uji parsial $(\mathrm{t})$ digunakan untuk menguji signifikansi pengaruh variabel independen servicescape dan harga secara parsial terhadap variabel dependen kepuasan pengunjung dengan menggunakan nilai standardize beta untuk melihat pengaruh dari variabel digunakan uji t.

Hasil perhitungan menunjukkan pengujian servicescape sebagai variabel independen menghasilkan $\mathrm{t}_{\text {hitung }}$ sebesar 3,632 dengan tingkat signifikansi $0,000<0,05$ artinya, servicescape berpengaruh secara signifikan terhadap kepuasan pengunjung. Pengujian harga sebagai variabel independen menghasilkan $t_{\text {hitung }}$ sebesar 2,838 dengan tingkat signifikansi $0,000<0,05$ artinya harga berpengaruh secara signifikan terhadap kepuasan pengunjung.

\section{Hasil Uji Secara Simultan (F)}

Pengujian ini bertujuan untuk menguji pengaruh variabel bebas (servicescape dan harga) terhadap kepuasan pengunjung. nilai $\mathrm{F}_{\text {hitung }}=14,067 \mathrm{~F}_{\text {tabel }}=$ 3,07 dengan signifikan $\mathrm{F}=0,000$ lebih kecil dari 0,05; menujukkan bahwa variabel independen servicescape (X1) dan harga (X2) secara simultan mempengaruhi variabel dependen kepuasan pengunjung (Y).

Tabel 1 Hasil pengujian Hipotesis

\begin{tabular}{lccccccc}
\hline \multirow{2}{*}{ Variabel Independen } & \multicolumn{2}{c}{ Unstandardized } & \multirow{2}{*}{ Coefficients } & Beta & $\mathbf{t}_{\text {hitumg }}$ & Sign. & \multirow{2}{*}{ Keterangan } \\
\cline { 2 - 5 } & $\boldsymbol{B}$ & Error & & & & & \\
\hline Servicescape (X1) & 0,409 & 0,144 & 0,311 & 3,632 & 0,000 & Signifikan & Harga (X2) \\
0,367 & 0,101 & 0,243 & 2,838 & 0,005 & Signifikan & Konstanta & 20,451 \\
$\mathrm{~N}$ & 120 & & & & & & \\
$\mathrm{R}$ & 0,691 & & & & & & \\
R Square & 0,498 & & & & & & \\
F hitung & 14,067 & & & & & & \\
Sign-F & 0,000 & & & & & & \\
\hline
\end{tabular}

Variabel Dependen $=$ Kepuasan pelanggan

\section{PEMBAHASAN}

\section{Pengaruh Servicescape Terhadap Kepuasan Pengunjung}

Hasil analisis statistik t untuk variabel servicescape diketahui bahwa nilai $t_{\text {hitung }}$ sebesar 4,353 dengan signifikansi sebesar 0,000 yang lebih kecil dari nilai signifikansi yang diharapkan $(0,05)$ menunjukkan bahwa variabel servicescape berpengaruh terhadap kepuasan pengunjung pada Museum Angkut Movie Star Studio Kota Batu, sehingga hipotesis diterima.

Penelitian ini konsisten dengan penelitian yang dilakukan oleh Musriha (2009) dan Manoppo (2013) yang menyatakan bahwa servicescape berpengaruh signifikan terhadap kepuasan nasabah. Lingkungan fisik merupakan satu wujud dari jasa itu sendiri, sehingga lingkungan fisik dapat mempengaruhi perilaku dan respon pengunjung terhadap jasa yang diberikan 
oleh pihak bank (Musriha, 2009). Lingkungan fisik merupakan hal yang sangat penting karena berdampak langsung pada kepuasan pengunjung. Pengaruh lingkungan fisik lebih berdampak besar jika perusahaan tersebut bergerak dibidang pariwisata seperti Museum Angkut Movie Star Studio Kota Batu.

Lingkungan fisik perusahaan yang didesain untuk kebutuhan karyawan dan pengunjung akan lebih memuaskan bagi para pengunjungnya daripada perusahaan yang tidak mempertimbangkan kebutuhan karyawan dan pengunjungnya. Hal ini menunjukkan bahwa pengunjung akan berusaha memaksimalkan kepuasannya dengan cara memilih tempat berlibur bersama keluarga atau teman yang menyediakan servicescape sesuai dengan kebutuhan mereka.

Dalam industri jasa pariwisata, servicescape dapat mempengaruhi minat pengunjung untuk mendatangi tempat pariwisata, menjauhi atau berniat untuk berkunjung kembali. Dari sini perusahaan dapat mengetahui bahwa serviscescape yang bagus akan membuat para pengunjung merasa nyaman dan puas dengan lingkungan fisik dan pelayanan yang diberikan. Sebaliknya, apabila serviscescape tidak sesuai dengan keinginan pengunjung maka akan menimbulkan rasa kurang nyaman dan mempengaruhi minat pengunjung untuk datang kembali.

\section{Pengaruh Harga Terhadap Kepuasan Pengun- jung}

Hasil analisis statistik t untuk variabel harga diketahui bahwa nilai $t_{\text {hitung }}$ harga sebesar 3,680 dengan signifikansi 0,000 . Nilai signifikansi harga $(0,000)$ yang lebih kecil dari nilai signifikansi yanng diharapkan $(0,05)$ menunjukkan bahwa variabel harga berpengaruh tehadap kepuasan pengunjung pada Museum Angkut Movie Star Studio Kota Batu, sehingga hipotesis diterima.

Hasil penelitian ini konsisten dengan penelitian yang dilakukan oleh Harjanto (2010) dan Adi (2012), yang menyatakan bahwa harga berpengaruh secara signifikan terhadap kepuasan pengunjung. Setiap perusahaan baik itu industri manufaktur maupun industri jasa dalam memasarkan produknya mempunyai tujuan. Secara umum tujuan perusahaan adalah mencapai dan meningkatkan keuntungan melalui volume penjualan yang menguntungkan, artinya laba itu dapat diperoleh dengan memuaskan pengunjung. Melalui laba, perusahaan dapat tumbuh dan berkembang dapat menggunakan kemampuan yang lebih besar, dapat memberikan tingkat kepuasan yang lebih besar kepa- da pengunjung serta dapat memperkuat kondisi perekonomian secara keseluruhan. Dapat pula dikatakan bahwa sebenarnya laba itu sendiri merupakan pencerminan dari usaha-usaha perusahaan yang berhasil memberikan kepuasan kepada pengunjung. Untuk memberikan kepuasan tersebut perusahaan dapat menyediakan atau menjual barang dan jasa yang paling baik dengan harga yang layak. Dalam menjalankan usahanya, pemilik usaha harus dapat menentukan strategi apa yang harus dipakai agar dapat menciptakan kepuasan pengunjung.

Namun, hasil penelitian ini tidak konsisten dengan penelitian yang dilakukan Silvia (2015) yang menyatakan bahwa secara parsial Harga berpengaruh tidak signifikan terhadap kepuasan pengunjung. Menurut Silvia (2015), penetapan harga terhadap suatu produk merupakan hal yang sangat penting, semakin tinggi manfaat produk atau jasa yang diberikan maka semakin tinggi nilai tukarnya dan semakin besar pula alat penukar yang harus di korbankan. Jika tidak terjadi transaksi jual beli terhadap suatu produk hal tersebut di karenakan harga yang di tawarkan terlalu tinggi dan tidak sesuai dengan daya beli pengunjung. Harga berpengaruh tidak signifikan terhadap kepuasan pengunjung. Artinya harga tidak mempengaruhi kepuasan pengunjung. Pengunjung tidak terlalu mementingkan harga dari produk yang ditawarkan namun memperhatikan faktor lainnya seperti cita rasa dan lingkungan fisik seperti pemandangan, tata letak perabotan, kebersihan dan kerapihan (servicescape).

\section{Pengaruh Dominan Antara Servicescape dan Harga Terhadap Kepuasan Pengunjung}

Hasil analisis statistik F servicescape dan harga secara simultan berpengaruh terhadap kepuasan pengunjung. Hasil pengujian simultan ini telah dinyatakan sebelumnya bahwa nilai $\mathrm{F}$ hitung sebesar 14,067 dengan signifikansi $F$ sebesar 0,000. Nilai signifikansi $(0,000)$ yang lebih kecil dari 0,05 menunjukkan bahwa $F$ servicescape dan harga secara bersama-sama berpengaruh terhadap kepuasan pengunjung pada Museum Angkut Movie Star Studio Kota Wisata Batu sehingga hipotesis diterima. Hasil dari penelitian ini menunjukkan nilai $R$ Square sebesar 0.498 yang berarti bahwa variabel-variabel $\mathrm{X}$ mempengaruhi 49,8\%, varibel Y,sedangkan sisanya sebesar $50,2 \%$ dijelaskan oleh variabel lain diluar penelitian ini.

Hasil penemuan ini konsisten dengan penelitian Silvia (2015) yang menyatakan bahwa servicescape 
dan harga secara silmultan berpengaruh signifikan terhadap kepuasan. Kepuasan pengunjung merupakan salah tujuan dari setiap perusahaan, untuk memenuhi kebutuhan pengunjung perusahaan bekerja keras menciptakan strategi yang jitu agar produknya mampu memberikan kepuasan serta mampu bersaing di pasar. Menghadapi persaingan yang ada perusahaan harus mampu menempatkan produknya ditengah-tengah persaingan bisnis yang semakin ketat. Upaya yang dilakukan perusahaan agar dapat memuaskan pengunjung dengan harapan pengunjung melakukan pembelian ulang. Tentunya memberikan nilai tambah bagi perusahaan di mana produk yang di tawarkan ternyata mampu bersaing di pasar dan perusahaan juga mendapatkan keuntungan. Keuntungan tersebut membawa usaha lebih luas dari hari ke hari, dengan menciptakan produk baru yang menarik dan unik membuat pengunjung loyal.

Kepuasan pengunjung dapat di pengaruhi oleh harga yang ditawarkan. Pengunjung akan merasa puas apabila jasa yang mereka peroleh ataupun di pengunjung ternyata berkualitas. Jasa yang dapat memenuhi kebutuhan serta dapat memuaskan konsumen, besar kemungkinan pengunjung akan datang kembali untuk melakukan pembelian. Penetapan harga terhadap suatu jasa merupakan hal yang sangat penting, semakin tinggi manfaat jasa yang diberikan maka semakin tinggi nilai tukarnya dan semakin besar pula alat penukar yang harus di korbankan. Jika tidak terjadi transaksi jual beli terhadap suatu jasa hal tersebut di karenakan harga yang di tawarkan terlalu tinggi dan tidak sesuai dengan daya beli pengunjung.

Faktor selanjutnya yang mempengaruhi kepuasan pengunjung adalah servicescape atau lingkungan fisik. Kondisi fisik dari lingkungan dimana di jadikan tempat untuk saling berinteraksi memainkan peranan yang sangat penting untuk memperkuat tingkat kepuasan dari pengunjung. Menata serta merancang sebuah ruangan semenarik mungkin dan memberikan kenyamanan, akan berunjung pada tingkat kepuasan pengunjung semakin tinggi.

Hasil analisis statistik uji t untuk variabel servicescape diketahui bahwa nilai unstandardized beta coefficient sebesar 0,409 dengan signifikansi sebesar 0,000. Sementara uji t untuk variabel harga diketahui bahwa nilai unstandardized beta coefficient harga sebesar 0,367 dengan signifikansi 0,005. Nilai unstandardized beta coefficient servicescape $(0,409)$ yang lebih besar dari harga $(0,367)$ menunjukkan bahwa variabel servicescape dominan pengaruhnya terhadap kepuasan pengunjung.
Hasil penelitian ini konsisten dengan penelitian yang dilakukan oleh Silvia (2015) yang menemukan bahwa nilai koefisien regresi dari servicescape dominan lebih besar daripada harga, yaitu 0,589>0,068. Menurut Silvia (2015) pengunjung tidak terlalu mementingkan harga dari jasa yang diberikan. Namun lebih memperhatikan faktor lain yang mempengaruhi kepuasan pengunjung yaitu lingkungan fisik seperti pemandangan, tata letak perabotan, kebersihan, kerapian dan pelayanan yang diberikan kepada pengunjung.

Servicescape merupakan fasilitas fisik perusahaan yang digunakan untuk mempengaruhi perasaan pengunjung agar menimbulkan rasa senang dan positif, Manoppo (2013). Dengan menciptakan suasana yang menyenangkan, rasa nyaman, pelayanan yang baik dan dapat memenuhi keinginan pengunjung, bukan tidak mungkin pengunjung akan menyampingkan harga yang ditetapkan. Walaupun harga yang ditawarkan semakin tinggi pengunjung akan tetap memakai jasa tersebut apabila servicescape yang diterapkan dapat memuaskan keinginan pengunjung dan dapat menimbulkan minat untuk berkunjung kembali. Dengan demikian dapat disimpulkan bahwa pada tingkat harga tertentu, jika manfaat yang dirasakan meningkat, maka nilainya akan meningkat pula. Apabila nilai yang dirasakan pelanggan semakin tinggi, maka akan menciptakan kepuasan pelanggan yang maksimal (Tjiptono, 2011).

\section{KESIMPULAN DAN SARAN}

\section{Kesimpulan}

Berdasarkan hasil penelitian dan pembahasan tentang pengaruh servicescape dan harga terhadap kepuasan pengunjung, maka dapat diambil kesimpulan sebagai berikut: Servicescape berpengaruh secara positif dan secara signifikan terhadap kepuasan pengunjung. Hasil penelitian ini menginformasikan bahwa ada hubungan yang signifikan antara variabel servicescape terhadap variabel kepuasan pengunjung di Museum Angkut Movie Star Studio Kota Batu. Harga berpengaruh secara positif dan secara signifikan terhadap kepuasan pengunjung. Hasil penelitian ini menginformasikan bahwa ada hubungan yang signifikan antara variabel harga terhadap variabel kepuasan pengunjung di Museum Angkut Movie Star Studio Kota Batu. Variabel servicescape berpengaruh dominan lebih besar dibandingkan dengan harga terhadap kepuasan pengunjung. 


\section{Saran}

Berdasarkan kesimpulan hasil penelitian, dapat diberikan saran untuk pihak manajemen dan peneliti selanjutnya. Bagi pihak manajemen Museum Angkut Movie Star Studio Kota Batu, mengingat servicescape memiliki pengaruh dominan lebih besar terhadap kepuasan pengunjung daripada harga maka, pihak manajemen perlu meningkatkan servicescape yang diterapkan dalam rangka meningkatkan kepuasan pengunjung terhadap jasa yang ditawarkan. Dalam penetapan harga, sebaiknya pihak manajemen dapat mempertimbangkan kesesuaikan harga tiket yang telah ditetapkan serta memberikan inovasi dengan sering mengadakan promo tiket masuk pada saat tertentu sehingga kepuasan pengunjung akan meningkat. Dari segi pelayanan pihak manajemen perlu melakukan review dalam meningkatkan pelayanan dan memberikan kepuasan pengunjung berupa nilai dan manfaat sehingga bisa dijadikan bahan evaluasi untuk membentuk minat berkunjung kembali. Bagi peneliti selanjutnya perlu penambahan variabel baru atau indikator baru untuk penelitian yang akan datang agar menghasilkan gambaran yang lebih luas tentang masalah penelitian yang sedang diteliti. Penelitian ini hanya memfokuskan pada pengaruh dua variabel independen tersebut dengan kepuasan pelanggan. Penelitian yang akan datang dapat diperluas pada pengaruhnya tidak hanya terhadap kepuasan pelanggan saja tetapi juga pada pengaruhnya terhadap loyalitas pelanggan.

\section{DAFTAR PUSTAKA}

Adi, Albertus. F. R. 2012. Analisis Pengaruh Harga, Kualitas Produk dan Kualitas Layanan Terhadap Kepuasan Pelanggan (Studi Kasus Pada Spesial
Sambal Cabang Lampersari Semarang). Jurusan Manajemen. Fakultas Ekonomi dan Bisnis. Universitas Diponegoro. Semarang.

Alma, Buchari. 2009. Manajemen Pemasaran \& Pemasaran Jasa. CV. Alfabeta: Bandung.

Harjanto, Nur Ryan. 2010. Analisis Pengaruh Harga, Produk, Kebersihan, dan Kaulitas Layanan Terhadap Kepuasan Pelanggan (Studi Kasus Pada Restoran Mamamia Cabang Mrican Semarang). Jurusan Manajemen. Fakultas Ekonomi. Universitas Diponegoro. Semarang.

Kotler, Philip; Armstrong, Garry. 2009. Prinsip-prinsip Pemasaran, Jilid 1. Erlangga: Jakarta.

Lengkong, Victor and Lumanauw Bode. 2008. Jurnal Megadigma. Vol.2 No.2.

Lovelock, Christopher. 2005. Service Marketing in Asia, 2 edition.

Lupiyoadi, Rambat dan Irawan. 2013. Manajemen Pemasaran Jasa. Salemba Empat: Jakarta.

Manoppo, Ferninda. 2013. Kualitas Pelayanan dan Servicescape Pengaruhnya Terhadap Kepuasan Konsumen Pada Hotel Gran Puri Manado. Jurnal issn 2303-1174. Univeritas Sam Ratulangi: Manado.

Musriha. 2009. Pengaruh Servicescape dan Kualitas Komunikasi Karyawan Terhadap Loyalitas Nasabah Melalui Kepuasan Nasabah Bank Mandiri di Surabaya. Fakultas Ekonomi dan Bisnis. Universitas Bhayangkara. Surabaya.

Tjiptono, Fandy. 2008. Strategi Pemasaran (3thed). Andy Offset: Yogyakarta. Yogyakarta.

Silvia, Mega. 2015. Pengaruh Kualitas Produk, Harga dan Servicescape terhadap Kepuasan Rumah Makan Ocean 27 Medan. Fakultas Ekonomi dan Bisnis. Universitas Sam Ratulangi: Manado.

Singarimbun, Masri dan Sofian Effendi. 2012 Metode Penelitian Survei. LP3ES: Jakarta. 